\title{
Social Media Marketing and Business Success of Automobile Dealers in Rivers State
}

\author{
N. Gladson Nwokah, Felix Lebete Aeenee \\ Department of Marketing, Faculty of Management Sciences, Rivers State University, Port Harcourt, Nigeria \\ Email: nwokah.gladson@ust.edu.ng
}

How to cite this paper: Nwokah, N.G. and Aeenee, F.L. (2017) Social Media Marketing and Business Success of Automobile Dealers in Rivers State. American Journal of Industrial and Business Management, 7 , 1298-1319.

https://doi.org/10.4236/ajibm.2017.712092

Received: November 1, 2017

Accepted: December 16, 2017

Published: December 19, 2017

Copyright $\odot 2017$ by authors and Scientific Research Publishing Inc. This work is licensed under the Creative Commons Attribution International License (CC BY 4.0).

http://creativecommons.org/licenses/by/4.0/

\begin{abstract}
This research study was carried out to empirically examine the relationship between social media marketing and business success of automobile car dealers in Rivers State, Nigeria. The study involved one hundred and sixty (160) respondents using questionnaire as the major instrument. After data cleaning one hundred and forty-three (143) copies of questionnaire were used for analysis with statistical tool Spearman Rank Order correlation coefficient with statistical package for social science (SPSS). It was found that there is a significant relationship between Facebook, Twitter and YouTube that significantly influenced sales growth, market share and profitability. The study concluded that Facebook, Twitter and YouTube significantly influence sales growth, market share and profitability of automobile car dealers in Rivers State. The study recommends amongst others that: Firms should make Facebook, Twitter and YouTube advertisement more catchy, appealing and trendy in order for online customers to patronize their products. The study suggested that more empirical research should be carried out on other social media platforms such as MySpace, LinkedIn, Friendster, Kyte and Istagram. This study further suggests that additional studies should be carried out in other states of the country so that we can compare the outcome with the present study.
\end{abstract}

\section{Keywords}

Social Media, Marketing, Business Success, Automobile, Rivers State

\section{Background of the Study}

The proliferation of digital economy has giving birth to internet-based business models in a vast array of industries and has dramatically changed the way companies deliver services to their customers, how they interact with clients and vehicles they use to market their products. We are living in a social era where 
business communications are rapidly evolving, driven by the growing ubiquity of new digital technologies, such as mobile devices and applications. As such, social media have dramatically altered how people interact with one another and firms. Social media are now indispensable to the survival of marketing operations [1]. Social media have altered the basic rules of interaction, making one way communication old fashioned. People are now able to communicate with their peers all over the world on a $24 / 7$ bases in the digital space, where a plethora of new tools enable real-time and user communication. At the same time, social media have enabled new communication channels for companies and allow them to reach current and potential customers, distribute their content, promote their product, monitor their brands and reputation as well as improve client retention and acquisition practices. Social media marketing is now used by organizations to take advantage of opportunities that online customers present. These strategies employed in social media marketing allow interaction, linkage and a sense of togetherness among its users [2]. Consequent upon customer's interest in online transactions, firms have not found it easy on how to make social media an integral part of their marketing philosophy. Most firms have approached social media as simply an avenue to engage in customer attraction and interaction while others employed it solely for marketing research activities or to seek opinion of customers [3].

Social media marketing (SMM) is a form of Internet marketing that utilizes social networking websites as a marketing tool [3]. According to [4], the use of social media has resulted to serious increase in the number of listening platforms that regulate online discussions which showed the opinion of customers via social media. According to [1], this contemporary use of online platforms has raised a plethora of agitations which the marketing researchers are expected to address. Presently, there is a narrow comprehension of social media behaviour among scholars. Consequently, researchers are handicapped on how best the volumes of opinions expressed in form of comments online should be interpreted. This has made organizations to depend on ordinary measures like overall number of comments. For example, most researchers have followed tweets as a way of monitoring respondents' engagement with offering activities like the Super Bowl [5] or the British Royal wedding [6]. Again, researchers have monitored total opinion shown in the text of comments posted to determine viewer's reactions to a product online [7] or to predict market performance [8]. It is not devoid of shortcomings, which have restricted scholars from accommodating social media as part of their research programs. To start with, social media platforms allow posts that are open ended and free form content where people are at liberty to say anything they feel like. Consequently, people speaking on a particular product may comment on various characteristics of the product, for example, customer's services versus reliability of the product itself or different products in the product portfolio. This is opposite of the traditionally employed survey in which researchers elicit responses pertaining to a particular topic of interest. The overall effect for online researchers is that simple metrics based on an 
aggregate across comments (e.g. average sentiment) can have several problems as they avoid established differences between products or attribute specific impressions [8].

Again, some website domain or venue may attract more positive (or more negative) persons to post which may depend on factors like format of the website domain, the type of audience as well as several other dynamics. Because of this, together with the mix of websites shown in the sample, noticed changes in overall metrics may just show transitions in the composition of data sample instead of any underlying transitions in overall perceptions of the product. Furthermore, the method of offline research conventionally control for such sampling biases whereas online sentiment measures routinely ignore them. Another problem is that of representativeness. In typical offline research, serious efforts are made to find people who would truly represent the population of interest. In online research, the opposite is the case as individuals self-select in their contributions [9]. For example, if a researcher is interested in measuring customer's satisfaction, any typical offline methodology would begin withdrawing a systematic and unbiased sample from the brand's customer base. On the other hand, methodologies using social media data appear to look at all posts, irrespective of whether those posts were done by customers or non-customers. Consequently, posted opinions may not precisely show examination of the product premised on experiences of customers. Because of these shortcomings, brand sentiment matrices gotten from all online comments are not to be compared to the measures gotten from typical offline research methods. Notwithstanding, the opinions shared on social media still provides information for marketing researchers. Despite the fact that various factors contributes to opinions posted online, the responses are the same influenced by the sentiments of the customer contributing towards the brand [10]. This underlying brand sentiment is differing from attribute specific evolutions [8]. So, in an effort to derive a metric of underlying brand sentiment from social media conversations, we expressly model and control for these later factors and differentiate their effect from that of the underlying brand sentiment on posted opinions.

There have been intensive studies on social media marketing in recent years. Most of them have attempted to identify factors influencing or contributing to social media marketing. For instance, [11] researched on social media marketing, measuring its effectiveness and identifying the target market and found that "social media marketing effectiveness is highly influenced by its messages/contents quality, the company's involvement, and its association with the other marketing platforms". According to [12] examined "the use of YouTube as a tourism marketing tool and found that YouTube provides tourists with an increased knowledge base, upon which they can make better informed decision". However, [13] studied 'impact of Facebook usage on students' academic achievement, role of self-regulation and trust and found that an extensive use of Facebook by students with extraverted personalities leads to poor academic performance". In spite of these, there appears to be no enough extant literature that 
has examined social media marketing and business success of automobile car dealers in Rivers State using the constructs such as Facebook, Twitter and YouTube. Obviously, this has created a literature gap that needs to be filled.

It has been observed that management of automobile car dealers have always relied on the traditional advertising strategies to create awareness of their product. During the last Auto trade fair in Port Harcourt, it was observed that different automobile car dealers, used the traditional advertising strategies in creating awareness for their stand location, product types and facilities and pay no attention to the huge opportunities offered by various social media platforms. To some extend these strategies have not been sufficient to attract business success. This constitutes a problem because customers are now searching for information online and no longer relying solely on the traditional advertising strategies. According to [4] social media marketing connect internet and share information between companies and potential customers. It allows convenience, interaction and relationship building with people and product or company. Even though there have been literatures on social media marketing, there seems to be no enough empirical marketing research addressing the relationship between social media marketing and business success of automobile car dealers in Rivers State. In the light of this and also to fill the gap, the researcher empirically investigate the relationship between social media marketing and business success. However, the researcher believes that improved information in the area of Facebook, Twitter and YouTube will enhance success that will in turn bring about sales growth, market share and profitability of automobile car dealers in Rivers State, Nigeria.

\section{Theoretical Foundation}

Relevant theories for this work are: Mcluhan's Media Theory, Social Exchange Theory and the Social Network Analysis (Theory).

\section{Mcluhan's Media Theory}

McLuhan was a philosopher and educator born in Canada. He reportedly authored the popular quote "the media is the message" [14]. He opined that the media has a major influence on people more than the content thereof. He submitted that the real messages people share will remain the same irrespective of the media used in communication. He further opined that the number of times of new communication form will affect our behaviour forever, and concluded that the impact of the media on the society far outweigh the media content.

Using Mcluhan's submissions, the power of the social media to change the users is not premised on its inherent content but as a result of the method of communication it employs. For instance, Twitter is limited to 140 characters which suppose that its functions can be done using blog service. Surprisingly, this limitation has given Twitter more advantage of getting product information easily spread.

\section{Social Exchange Theory}

According to [15], the origin of social exchange theory could be traced to stu- 
dies drawn from sociology which typically explores the exchange that exists between people and/or small groups. The model majorly analyses how individuals interacts with one another, develop relationships, bonds and the establishment of communities through exchange of communications with the use of "cost benefit framework and comparison of alternatives" [16]. It further states that people participates in behaviour that rewards them and neglects those that appear expensive. Simply put, people's social behaviour is premised on their inherent evaluation of what is spent-received from been part of a particular social exchange.

Some scholars argued that the theory is best and succinctly distilled in the works of [16] who wrote.

Social behaviour is an exchange of goods, material goods but also non-material ones, such as the symbols of approval or prestige. Persons that give much to others try to get much from them. This process of influence tends to work out at equilibrium to balance in the exchange. For a person in an exchange, what he gives may be a cost to him, just as what he gets may be a reward, and his behaviour changes less as the difference of the two, profit, tends to a maximum.

Individuals participate in social exchange because of the following reasons:

1) The prospect of gaining a famous reputation or exerting greater influence on others.

2) Expected reciprocity by other individuals.

3) Altruism as well as

4) Express reward.

\section{Social Network Analysis (Theory)}

According to [17] Social Network theory sees the conference of people as connected participants and employs mathematical models to examine its developmental structure and evaluation. This theory looks at personal actors in a community as nodes. The pattern of interaction between these participants is described as "ties, edges, links, or connections". These networks can be formed at the individual level, to family level, as well as communities and national levels. The ties could manifest as friendship, financial exchange, frequency of communication as well as the same believe or interest. Combined, they provide an elaborate graph structure mathematical calculation which could be done using the complex graph. Connecting or equating this to online conversation could inform automobile car dealers in Rivers State metropolis and beyond of the methods of promoting their products through organic word-of-mouth. Recently, results from the use of multidimensional social network analysis to web 2.0 have been highly productive [17].

\section{Concept of Social Media Marketing}

Social media marketing employed social networking sites to promote products and services via the internet. Social media sites are useful for building business networks, and for exchanging ideas. The meaning of social media can be derived from two words that constitute it. Social is the medium to socialize. It implies 
the interaction of people within a group or community while Media refers to means of communication via publication. Taken together, [18] perceived social media as communication platforms that are generated and sustained by the interpersonal interaction of individuals through the specific medium or tool. According to [1], social media is describes as the "democratization of information, transforming people from content readers to content publishers". It is the shift from a broadcast mechanism to a many-to-many model, rooted in conversations between authors, people, and peers [19]. Perceived social media as "a group of online based applications that build on the ideas and technology of web 2.0 that allows the creation and exchange of user-generated content". Social media is about networking and networking is a way that espouses trust among parties and communities involved. Website that allows its users to share content, opinion and promote interaction and community building can be classified as social media. [1] identifies some attributes distinguishing today's social media interaction from other types of social conversations to include:

- One-to-many or many-to-many interactions

- Easy to use

- Accessibility (everyone) high scalable (everyone + everywhere), and functions in real time (everyone + everywhere + everytime).

- Entirely public and transparent [1].

Social media represent low-cost tools that are employed to combine technology and social interaction with the use of words. These tools are include Twitter, Facebook, My Space, YouTube and other social networking sites collectively referred to as social media [18]. Social Media Marketing is the means of acquiring websites traffic via social sites. In the view of [20] social media marketing SMM "is a term which describes the actual acts of using social networks for marketing purpose". [21] notes that Social media marketing focus on people not product. He stresses that the product can be presented with qualitative features and promotional tools but what matters is the comments and appreciations left by the customers. [22] supported the view of [21] that content is provided by people and this is the reason why social media marketing is so challenging to marketers. [18] describes SMM as ways of using social media to convince consumers that one's company, products and/or services are available. According to [9], SMM is viewed as ways of promoting products or services online by attracting customers to discuss and make suggestions about the products or services using the internet. The term social marketing is elucidated by [1] as involved with the applicability of marketing philosophies and practice to strengthen social as well as economic ends. It is also concerned with the analysis of the social consequences of marketing policies, decision and activities. Social media marketing is not merely about hitting the frontpage of Facebook or any other social news website. It is a strategic methodical process to establish the company's influence, reputation and brand within communities of potential customers, readers and supporters. Social media marketing programs usually anchored on the ability to create con- 
tent that attract users and encourage them to share it with others. Social media is easily accessible to users with internet access. Online interaction with organizations enables brand awareness and often enhances customer service. Social media serves as a relative low-cost platform for organization to implement marketing campaign.

Social networking websites allow people to communicate with one another and build relationships. When organizational profiles are created, users can interact freely with the product. [9] noted that these interactions are personal to users owing to previous experiences with social networking site interactions. Networking sites allow users to retweet or share comments made about their products online. Through liking, sharing or retweeting messages and comments about products online, other users connected are able to view the message, therefore reaching more people. Social networking sites act as word of mouth because the information about a brand is being put out there and getting repeated, more traffic is brought to the product company. As a result of networking sites, firms can interact and share information with users. This personal interaction can establish a feeling of commitment into followers and potential customers. Also, by choosing whom to follow on these sites, products can reach a wider target audience.

Social media applications enable online users in business to interact and share opinion about a product. Each participating customer is part of the marketing department, because other customers read their comments or reviews. The engagement process is then essential to successful social media marketing.

\section{Dimensions of Social Media Marketing}

\section{1) Facebook and Business Success}

Facebook is a social site where users create individual or organizational profile which enable them to post comments, or like comments posted by others, share photographs, stream live video, play games, chat live, and links to news including content shared online can be made publicly, or shared only in a chat group or with friends, family as well as single individual. Facebook began in February of 2004 at Harvard University. The Social networking website came into existence by Mark Zuckerbeg along with Edward Saverin. The original idea behind the project was the creation of an online social platform for Harvard students and alumni. However, the concept of an online profile to communicate with friends, gained huge popularity and very quickly spread across other universities and educational institutions eventually becoming available to the non-academic public in September 2006 [23]. Social media changed the way of marketing dynamics and made the consumers an active element of marketing communication. Instead of passively receiving the communicated messages, its empowers people to contribute, share information with expectation of quick accomplishment of this process [2]. Facebook is the leading social network utilized by marketers [5]. It provides a marketing and advertising platform Facebook for Business (FBFB), that aims to help with increasing sales, generating leads and raising 
brand awareness. Facebook is another way to create and foster a community around a product. It provides two-way interaction between the brand and the customers. With its many marketing platform and features, Facebook has proven to be essential and unique for any type of business if you still don't have a Facebook account for your business, it is imperative to start now to experiment how this social networking giant can assist in the attainment of your business goals. Thus the following hypothesis is formulated.

$\mathrm{Ho}_{1}$ : There is no significant relationship between Facebook and sales growth of automobile car dealers in Rivers State.

$\mathrm{Ho}_{2}$ : There is no significant relationship between Facebook and market share of automobile car dealers in Rivers State.

$\mathrm{Ho}_{3}$ : There is no significant relationship between Facebook and profitability of automobile car dealers in Rivers State.

\section{2) Twitter and Business Success}

Twitter is a social networking and micro blogging service that enable its users to send and read text-based messages up to one hundred and forty characters, known as "tweets".

Twitter was created in March 21, 2006 and launched in July 15 same year by Jack Dorsey, Noah Class, Evan Williams and Biz Stone. The website increasingly gained worldwide popularity, with over 319 million active users as of 2016, generating millions tweets daily and accommodating 1.6 billion search queries per day [2]. Since the launch of twitter, it has become one among the top 10 most visited websites on the internet, and has been described "as the SMS of the internet" [24]. Twitter enables its users to make short posts about anything, but users are limited to only 140 characters in length, that of single SMS message. The short posts are called "tweets", of the chirping of birds. This appears chronologically on the Twitter profile page. Besides posting, users also follow others on the site to get the latest tweets in the twitter feed. Conversely, if someone follows you, they get your tweets in their feeds. That is to say, the more followers a user have the greater the potential reach. Twitter enables firms to advertise products on an individual level. Product usefulness can expressed in short messages that followers are likely to read. These messages are shown on user's home pages. Messages can also link to the firm's website, Facebook profile, and other social sites. This link avail the followers more opportunity to spend time interacting with the product online. This interaction can create business connection between product and customer can also lead to advertising opportunities. Twitter is also a great news source for any business. Monitoring what consumers are saying about your product, brand, company or service is a tool not accessible before social media. Also, the ability to monitor what users are saying is vital for building trust among your brand. Thus the following hypotheses are formulated.

$\mathrm{Ho}_{4}$ : There is no significant relationship between Twitter and Sales growth of automobile car dealers in Rivers State.

$\mathrm{Ho}_{5}$ : There is no significant relationship between Twitter and Market share of automobile car dealers in Rivers State. 
$\mathrm{Ho}_{6}$ : There is no significant relationship between Twitter and Profitability of automobile car dealers in Rivers State.

\section{3) YouTube and Business Success}

YouTube is an online platform, to watch, share and promote original video content on the web. [25] observed that YouTube perceives itself as a community where users are inspired, informed, entertainment, and educated via watching and sharing of video. YouTube is featured with Google Adwords for video, hosting providing the avenue for business that are interested in reaching current and potential customers with online video promotion. YouTube uses Adobe flash video and HTML5 technology to showcase a wide variety of user-generated content, including movie clips, and music videos, as well as content including video blogging and short original videos. YouTube was founded in February 2005 as a video hosting site founders include Chad Hurley, Steve Chen, and Jawed Karim. They were all early employees of PayPal. Chad Hurley attended Indiana University of Pensylvania and studied design, Steve Chen and Jawed Karim attended University of Illinois at Urbana-Champaign and both studied computer sciences (Andrew, 2013). The company started operation in December of 2005 after it received start up fund from sequoia capital, of mento park, California. Google obtained it for $\$ 1.65$ billion in stock a year later, in November 2006 [25]. [12] noted that the first video shown on YouTube was launched at about 8:27 pm on Saturday April 23 $3^{\text {rd }}, 2005$. One of the co-founders Jawed Karim posted a video of his brief visit to San Diego Zoo. Karim talks about elephant's trucks in the video titled "me at zoo". YouTube was launched in Lagos, Nigeria on 7 December, 2011. According to an online media news (8 Dec. 2011), Nigerians are passionate about music, entertainment and many other genres that YouTube offers and that by Launching YouTube locally, will help people to find the most popular videos in Nigeria along with those that are rising in popularity. Content uploaded by Nigerian users will show up as browse pages on the YouTube Nigeria site, creating a virtual space for the national community and giving Nigeria the opportunity to increase their exposure online. YouTube ads usually in sync with the content of the video asked for; this is another advantage YouTube brings for advertisers. Certain ads are presented with certain video since the content is important. Promotional opportunities such as sponsoring a video is also possible on YouTube, for instance, users searching for online video about cars may be viewing sponsored video from an automotive company in results along with other related videos. Thus the following hypotheses were formulated.

$\mathrm{Ho}_{7}$ : There is no significant relationship between YouTube and sales growth of automobile car dealers in Rivers State.

$\mathrm{Ho}_{8}$ : There is no significant relationship between YouTube and market share of automobile car dealers in Rivers State.

$\mathrm{Ho}_{\text {g }}$ : There is no significant relationship between YouTube and profitability of automobile car dealers in Rivers State.

4) Business Success

It is pertinent to note that the major purpose of establishing a business is to 
make profit, achieve success and ensure the continuous existence. However, a successful business is one that produces an acceptable return on investment. Business success is that which is positioned to keep on running without depending on the owner to be in daily attendance [8]. In this regard, the success of any business is therefore, very crucial to the owner(s) and as such, the owners joy is as a result of the success of the business. [11] noted that successful business is:

An organization that:

* Ensure current customers are delighted and

* Acquires new customers while,

* Making a profit.

[25] describes business success as the capacity of the business to attain its stated objective. Business success has to do with the achievement of the business with respect to its business goals. It is having set goal and achieving them. Similarly, [26] business success tends to provide information on efficiency, growth, profit, size, liquidity, success/failure, market share and leverage. It presents information on the business growth, success/failure as well as the profitability of the business. In this vein, business success indicates that the business is profitable, effective, efficient, and successful.

As can be seen in Figure 1, it is operationalized that dimensions of social media marketing have influence on the measures of business success. Thus the linear lines indicate the hypothesized relationship between the dependent and independent variables which is mediated by power supply.

\section{Research Design}

Research design is perceived as a plan, structure and strategy of investigation used in order to elicit answers to research questions as validly, objectively, accurately and economically as possible [27]. This indicates that a research design is a logical model which guides the research in various stages of the investigation. For the purpose of this study, survey design was employed. A survey method refers to a strategy in which a representative sample of a population is studied and the result generalized. [28] argued that a population means the entire persons, organization, group of persons or things the researcher wishes to examine. The study population consists of the forty (40) automobile car dealers registered with Rivers State branch of Automobile Dealers Association of Nigeria as at January 2017 when the survey commenced. However, the study population is made up of marketing executives and media officers from each of the forty (40) registered automobile car dealers in Rivers State. Sampling is the systematic process of selecting, picking or drawing elements or items as sample from a population which will represent the wide population. The population of interest of this study covers the marketing executives and media officers of the 40 automobile car dealers in Rivers State. However the total number of marketing executives and media officers of these firms surveyed were not given due to information restrictions of these firms to external parties. This made the use of quantitative method in 


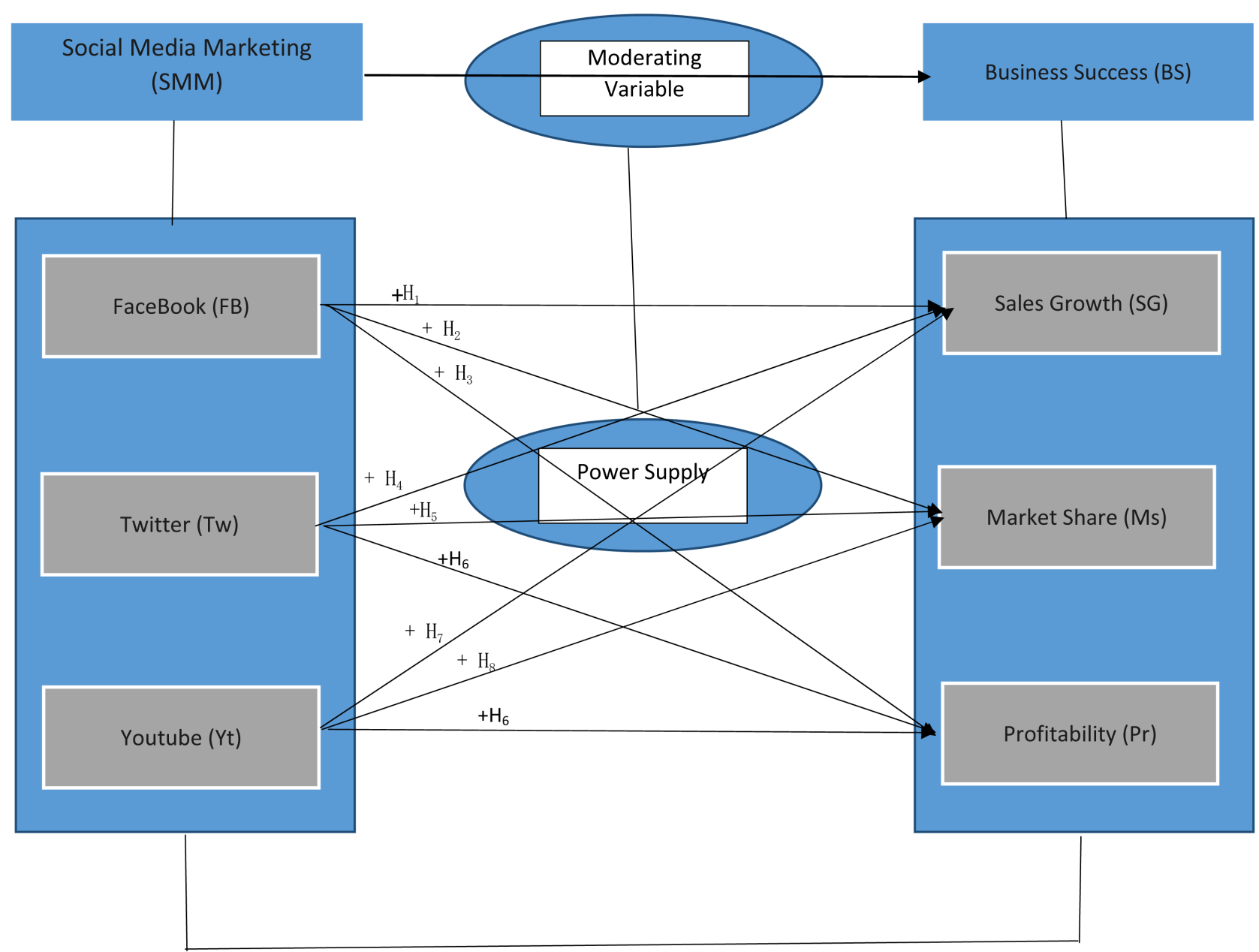

Figure 1. Operationalization of social media marketing and business success of automobile car dealers in rivers state. Source: Researchers conceptualization.

ascertaining the sample size a difficulty. The judgmental sampling technique was used in determining the sample size which gives the researcher the freedom to pick sample size. Four (4) respondents comprises of two (2) marketing executives and two (2) media officers from each of the forty (40) automobile car dealers were selected to constitute the sample size for this research study. This brings a total of $160(40 \times 4)$ respondents. Data used for this research are sourced mostly from the questionnaire. The researcher obtained primary data through distribution of one hundred and sixty (160) copies of questionnaires to the respective respondents of the automobile car dealers that constituted our sample for the study. However only 143 copies were valid and were used for further data analysis. The questions are designed using the five point Likert scale ranging from Not At All (NAA), Slight Extent (SE), Moderate Extent (ME), Considerable Extent (CE) and Great Extent (GE). Also, the researcher in carrying out this research made use of the secondary data which include data from academic articles in referred journals, relevant textbooks and the internet. However, questionnaire was therefore the major instrument of data collection. 


\section{Data Analysis}

The secondary data analysis was conducted using the Spearman rank order correlation tool at a 95\% confidence interval. Specifically, the tests cover hypotheses $\mathrm{Ho}_{1}$ to $\mathrm{Ho}_{10}$ which are bivariate and all formulated in the null form. We have relied on the Spearman Rank ( $r h o$ ) statistic was relied on to undertake the analysis. The 0.05 significance level is applied as criterion for the probability of either accepting the null hypotheses at $(p>0.05)$ or rejecting the null hypotheses at $(p<$ 0.05).

\section{Relationship between Facebook and the Measures of Business Success:}

Table 1 illustrates the test for the three previously postulated hypotheses.

$\mathrm{Ho}_{1}$ : There is no significant relationship between Facebook and sales growth of automobile car dealers in Rivers State

Data results reveal that there is a strong positive relationship exists between Facebook and sales growth. The rho value 0.735 indicates this relationship and it is significant at $p=0.000<0.01$.

$\mathrm{Ho}_{2}$ : There is no significant relationship between Facebook and market share of automobile car dealers in Rivers State.

Data results reveal that there is a strong positive relationship exists between Facebook and Market Share. The rho value 0.320 indicates this relationship and it is significant at $p=0.000<0.01$.

$\mathrm{Ho}_{3}$ : There is no significant relationship between Facebook and profitability of automobile car dealers in Rivers State.

Data results reveal that there is a strong positive relationship exists between Facebook and profitability. The rho value 0.705 indicates this relationship and it is significant at $p=0.000<0.01$.

Table 1. Correlation matrix for the relationship between Facebook and business success.

\begin{tabular}{|c|c|c|c|c|c|c|}
\hline & & & $\begin{array}{l}\text { Face } \\
\text { book }\end{array}$ & $\begin{array}{l}\text { Sales } \\
\text { Growth }\end{array}$ & $\begin{array}{l}\text { Market } \\
\text { Share }\end{array}$ & Profitability \\
\hline \multirow{12}{*}{$\begin{array}{l}\text { Spearman's } \\
\text { rho }\end{array}$} & \multirow{3}{*}{ Facebook } & Correlation Coefficient & 1.000 & $0.735^{\star *}$ & $0.320^{\star \star}$ & $0.705^{\star *}$ \\
\hline & & Sig. (2-tailed) & & 0.000 & 0.000 & 0.000 \\
\hline & & $\mathrm{N}$ & 143 & 143 & 143 & 143 \\
\hline & \multirow{3}{*}{$\begin{array}{l}\text { Sales } \\
\text { Growth }\end{array}$} & Correlation Coefficient & $0.735^{\star *}$ & 1.000 & $0.494^{\star *}$ & $0.767^{\star \star}$ \\
\hline & & Sig. (2-tailed) & 0.000 & & 0.000 & 0.000 \\
\hline & & $\mathrm{N}$ & 143 & 143 & 143 & 143 \\
\hline & \multirow{3}{*}{$\begin{array}{l}\text { Market } \\
\text { Share }\end{array}$} & Correlation Coefficient & $0.320^{\star *}$ & $0.494^{\star *}$ & 1.000 & $0.203^{*}$ \\
\hline & & Sig. (2-tailed) & 0.000 & 0.000 & & 0.015 \\
\hline & & $\mathrm{N}$ & 143 & 143 & 143 & 143 \\
\hline & \multirow{3}{*}{ Profitability } & Correlation Coefficient & $0.705^{\star *}$ & $0.767^{\star *}$ & $0.203^{*}$ & 1.000 \\
\hline & & Sig. (2-tailed) & 0.000 & 0.000 & 0.015 & \\
\hline & & $\mathrm{N}$ & 143 & 143 & 143 & 143 \\
\hline
\end{tabular}

Correlation is significant at the 0.01 level (2-tailed). Correlation is significant at the 0.05 level (2-tailed). Source: Research Data June, 2017 (SPSS output, version 21.0). 
Therefore, based on empirical findings, all previously stated bivariate null hypothetical statements are hereby rejected and the alternate is accepted. Thus, the study finds that:

$\mathrm{Ha}_{1}$ : There is a significant relationship between Facebook and sales growth of automobile car dealers in Rivers State.

$\mathrm{Ha}_{2}$ : There is a significant relationship between Facebook and market share of automobile car dealers in Rivers State.

$\mathrm{Ha}_{3}$ : There is a significant relationship between Facebook and profitability of automobile car dealers in Rivers State.

Table 2 illustrates the test for the three previously postulated hypotheses

$\mathrm{Ho}_{4}$ : There is no significant relationship between Twitter and sales growth of automobile car dealers in Rivers State.

Data results reveal that there is a strong positive relationship exists between Twitter and sales growth.The rho value 0.873 indicates this relationship and it is significant at $p=0.000<0.01$.

$\mathrm{Ho}_{5}$ : There is no significant relationship between Twitter and market share of automobile car dealers in Rivers State.

Data results reveal that there is a strong positive relationship exists between Twitter and market share. The rho value 0.379 indicates this relationship and it is significant at $p=0.000<0.01$.

$\mathrm{Ho}_{6}$ : There is no significant relationship between Twitter and profitability of automobile car dealers in Rivers State.

Table 2. Relationship between twitter and the measures of business success.

\begin{tabular}{|c|c|c|c|c|c|c|}
\hline \multicolumn{7}{|c|}{$\begin{array}{l}\text { Correlation Matrix for the Relationship between } \\
\text { Twitter and the Measures Business Success }\end{array}$} \\
\hline & & & Twitter & $\begin{array}{l}\text { Sales } \\
\text { Growth }\end{array}$ & $\begin{array}{c}\text { Market } \\
\text { Share }\end{array}$ & Profitability \\
\hline \multirow{12}{*}{$\begin{array}{l}\text { Spearman's } \\
\text { rho }\end{array}$} & & Correlation Coefficient & 1.000 & $0.873^{\star *}$ & $0.379^{\star *}$ & $0.789^{\star *}$ \\
\hline & Twitter & Sig. (2-tailed) & & 0.000 & 0.000 & 0.000 \\
\hline & & $\mathrm{N}$ & 143 & 143 & 143 & 143 \\
\hline & & Correlation Coefficient & $0.873^{* *}$ & 1.000 & $0.494^{\star *}$ & $0.767^{\star *}$ \\
\hline & $\begin{array}{l}\text { Sales } \\
\text { Growth }\end{array}$ & Sig. (2-tailed) & 0.000 & & 0.000 & 0.000 \\
\hline & & $\mathrm{N}$ & 143 & 143 & 143 & 143 \\
\hline & & Correlation Coefficient & $0.379^{* *}$ & $0.494^{* *}$ & 1.000 & $0.203^{*}$ \\
\hline & $\begin{array}{l}\text { Market } \\
\text { Share }\end{array}$ & Sig. (2-tailed) & 0.000 & 0.000 & & 0.015 \\
\hline & & $\mathrm{N}$ & 143 & 143 & 143 & 143 \\
\hline & & Correlation Coefficient & $0.789^{* *}$ & $0.767^{\star *}$ & $0.203^{*}$ & 1.000 \\
\hline & Profitability & Sig. (2-tailed) & 0.000 & 0.000 & 0.015 & \\
\hline & & $\mathrm{N}$ & 143 & 143 & 143 & 143 \\
\hline
\end{tabular}

Correlation is significant at the 0.01 level (2-tailed). Correlation is significant at the 0.05 level (2-tailed). Source: Research Data June, 2017 (SPSS output, version 21.0). 
Data results reveal that there is a strong positive relationship exists between Twitter and profitability. The rho value 0.789 indicates this relationship and it is significant at $p=0.000<0.01$.

Therefore, based on empirical findings, all previously stated bivariate null hypothetical statements are hereby rejected and the alternate is accepted. Thus, the study finds that:

$\mathrm{Ha}_{4}$ : There is a significant relationship between Twitter and sales growth of automobile car dealers in Rivers State.

$\mathrm{Ha}_{5}$ : There is a significant relationship between Twitter and market share of automobile car dealers in Rivers State.

$\mathrm{Ha}_{6}$ : There is a significant relationship between Twitter and profitability of automobile car dealers in Rivers State.

Relationship between YouTube and the Measures of Business Success

Table 3 illustrates the test for the three previously postulated hypotheses.

$\mathrm{Ho}_{7}$ : There is no significant relationship between YouTube and sales growth of automobile car dealers in Rivers State.

Data results reveal that there is a strong positive relationship exists between YouTube and sales growth. The rho value 0.870 indicates the strength and magnitude of this relationship and it is significant at $p=0.000<0.01$.

$\mathrm{Ho}_{8}$ : There is no significant relationship between YouTube and market share of automobile car dealers in Rivers State.

Data results reveal that there is a strong positive relationship exists between YouTube and market share. The rho value 0.490 indicates the strength and magnitude of this relationship and it is significant at $p=0.000<0.01$.

Table 3. Correlation matrix for the relationship between YouTube and the measures of business success.

\begin{tabular}{|c|c|c|c|c|c|c|}
\hline & & & $\begin{array}{l}\text { You } \\
\text { tube }\end{array}$ & $\begin{array}{l}\text { Sales } \\
\text { Growth }\end{array}$ & $\begin{array}{l}\text { Market } \\
\text { Share }\end{array}$ & Profitability \\
\hline \multirow{12}{*}{$\begin{array}{l}\text { Spearman's } \\
\text { rho }\end{array}$} & \multirow{3}{*}{ YouTube } & Correlation Coefficient & 1.000 & $0.870^{* *}$ & $0.490^{* *}$ & $0.753^{* *}$ \\
\hline & & Sig. (2-tailed) & & 0.000 & 0.000 & 0.000 \\
\hline & & $\mathrm{N}$ & 143 & 143 & 143 & 143 \\
\hline & \multirow{3}{*}{$\begin{array}{c}\text { Sales } \\
\text { Growth }\end{array}$} & Correlation Coefficient & $0.870^{\star *}$ & 1.000 & $0.494^{* *}$ & $0.767^{\star *}$ \\
\hline & & Sig. (2-tailed) & 0.000 & & 0.000 & 0.000 \\
\hline & & $\mathrm{N}$ & 143 & 143 & 143 & 143 \\
\hline & \multirow{3}{*}{$\begin{array}{l}\text { Market } \\
\text { Share }\end{array}$} & Correlation Coefficient & $0.490^{\star *}$ & $0.494^{* *}$ & 1.000 & $0.203^{*}$ \\
\hline & & Sig. (2-tailed) & 0.000 & 0.000 & & 0.015 \\
\hline & & $\mathrm{N}$ & 143 & 143 & 143 & 143 \\
\hline & \multirow{3}{*}{ Profitability } & Correlation Coefficient & $0.753^{* *}$ & $0.767^{* *}$ & $0.203^{*}$ & 1.000 \\
\hline & & Sig. (2-tailed) & 0.000 & 0.000 & 0.015 & \\
\hline & & $\mathrm{N}$ & 143 & 143 & 143 & 143 \\
\hline
\end{tabular}

Correlation is significant at the 0.01 level (2-tailed). Correlation is significant at the 0.05 level (2-tailed). Source: Research Data June, 2017 (SPSS output, version 21.0). 
$\mathrm{Ho}_{9}$ : There is no significant relationship between YouTube and profitability of automobile car dealers in Rivers State.

Data results reveal that there is a strong positive relationship exists between YouTube and profitability. The rho value 0.753 indicates the strength and magnitude of this relationship and it is significant at $p=0.000<0.01$. Therefore, based on empirical findings, all previously stated bivariate null hypothetical statements are hereby rejected and the alternate is accepted. Thus, the study revealed that:

$\mathrm{Ha}_{7}$ : There is a significant relationship between YouTube and sales growth of automobile car dealers in Rivers State.

$\mathrm{Ha}_{8}$ : There is a significant relationship between YouTube and market share of automobile car dealers in Rivers State.

$\mathrm{Ha}_{9}$ : There is a significant relationship between YouTube and profitability of automobile car dealers in Rivers State.

Testing the Significance of the Moderating Influence of Power Supply on the Relationship between Social Media Marketing and Business Success.

In Table 4, the zero-order correlation between social media marketing and business success shows the correlation coefficient where Power Supply is not moderating the variables; and this is, indeed, both fairly high (0.881) and statistically significant $(p$-value $(=0.000)<0.05)$. The partial correlation controlling

Table 4. Moderating influence of power supply on the relationship between social media marketing and business success.

\begin{tabular}{|c|c|c|c|c|c|}
\hline \multicolumn{3}{|c|}{ Control Variables } & \multirow{2}{*}{$\begin{array}{c}\text { Social Media } \\
\text { Marketing }\end{array}$} & \multirow{2}{*}{$\begin{array}{c}\begin{array}{c}\text { Business } \\
\text { Success }\end{array} \\
0.881\end{array}$} & \multirow{2}{*}{$\begin{array}{c}\begin{array}{c}\text { Power } \\
\text { Supply }\end{array} \\
0.902\end{array}$} \\
\hline & & Correlation & & & \\
\hline & $\begin{array}{c}\text { Social Media } \\
\text { Marketing }\end{array}$ & Significance (2-tailed) & & 0.000 & 0.000 \\
\hline & & Df & 0 & 141 & 141 \\
\hline & & Correlation & 0.881 & 1.000 & 0.875 \\
\hline \multirow[t]{7}{*}{-none- ${ }^{a}$} & $\begin{array}{l}\text { Business } \\
\text { Success }\end{array}$ & Significance (2-tailed) & 0.000 & & 0.000 \\
\hline & & Df & 141 & 0 & 141 \\
\hline & & Correlation & 0.902 & 0.875 & 1.000 \\
\hline & $\begin{array}{l}\text { Power } \\
\text { Supply }\end{array}$ & Significance (2-tailed) & 0.000 & 0.000 & \\
\hline & & Df & 141 & 141 & 0 \\
\hline & & Correlation & 1.000 & 0.440 & \\
\hline & $\begin{array}{c}\text { Social Media } \\
\text { Marketing }\end{array}$ & Significance (2-tailed) & & 0.000 & \\
\hline \multirow{4}{*}{$\begin{array}{l}\text { Power } \\
\text { Supply }\end{array}$} & & Df & 0 & 140 & \\
\hline & & Correlation & 0.440 & 1.000 & \\
\hline & $\begin{array}{l}\text { Business } \\
\text { Success }\end{array}$ & Significance (2-tailed) & 0.000 & . & \\
\hline & & Df & 140 & 0 & \\
\hline
\end{tabular}

a. Cells contain zero-order (Pearson) correlations. Source: Research Data June, 2017 (SPSS output, version 21.0). 
for Power Supply, however, is (0.440) and statistically significant ( $p$-value $(=0.000)$ $<0.05$ ). Looking at the zero correlation, we find that both Social Media Marketing and Business Success are highly positively correlated with Power Supply, the control variable. Removing the effect of this control variable reduces the correlation between the other two variables to be 0.440 and significant at $\alpha=0.05$, therefore the null hypothesis is rejected and we conclude that:

$\mathrm{Ha}_{10}$ : Power Supply significantly moderates the relationship between Social Media Marketing and Business Success of automobile car dealers in Rivers State.

\section{Discussion of Findings}

In this section, an attempt is made to examine in detail what the research findings depicts. The findings are discussed by relating them to previous related literature. We therefore begin with the discussion relationship between Facebook and business success which is measured by sales growth, market share and profitability.

\section{Relationship between Facebook and business success}

The test of hypotheses one, two, and three in Table 1, shows that there is a strong positive relationship between Facebook and each of the measures of business success in the sample of automobile car dealers in Rivers State. The positive values of $(0.735,0.320$ and 0.705$)$ show the strength of the relationships between the variables. The $p$-value $(0.00)$ is less than the level of significance at (0.05). Therefore, this suggests that a strong and positive relationship exists between Facebook, sales growth, market share and profitability. Hence, the null hypotheses are hereby rejected and the alternative hypothesis accepted. However, this findings corroborates with the views of [29] that Facebook is the leading social network utilized by marketers (It provides a marketing and advertising platform Facebook for Business (FBFB), that aims to help with increasing sales, generating leads and raising brand awareness. Aside from posting content and interacting with fans on a fan page, marketers can utilize the advertisement system, known also as Facebook Ads. Our finding further aligns with [21] which sums up that: "Facebook has not only transformed the research and purchase consideration phase, but it has also provided shoppers with a platform to advocate the products and stores they like". Facebook showcases an entirely new way of scrutinizing a product or brand. In line with Robert's view, it is also the possible to measure the effectiveness of brand exposure on the Facebook platform. From the foregoing discourse, it is concluded that Facebook is a great platform for advertisers to make their products known across different social groups and backgrounds profitably.

\section{Relationship between Twitter and Business Success}

The test of hypotheses four, five and six as shown in Table 2 depicts that a strong and positive relationship exist between Twitter and each of the measures of business success in the sample of automobile car dealers in Rivers State. The positive values of $(0.873),(0.379)$ and $(0.789)$ show the strength of the relationships between the variables. Furthermore, the $p$-value $(0.00)$ is less than the level 
of significance of (0.05), therefore we reject the null hypotheses and conclude that a positive and significant relationship exists between Twitter, sales growth, market share and profitability. This finding however supports the views of [24] that "Twitter is a versatile tool, used for socio-political campaigns, citizen journalism and increasingly for marketing purposes, with companies like Dell reporting to have gained $£ 1.9$ million from sales and cost savings via Twitter Practitioners also predict that Twitter will play a major part in social commerce phenomenon that could significantly affect business models online". From the foregoing discourse, it can be concluded that Twitter is a platform that promotes a product in real-time and brings customers in.

\section{Relationship between YouTube and Business Success}

The test of hypotheses seven, eight and nine as shown in Table 3 depicts that a strong and positive relationship exist between Youtube and each of the measures of business success in the sample of automobile car dealers in Rivers State. The positive large values of $(0.870),(0.490)$ and $(0.753)$ show the strength of the relationships between the variables. Furthermore, the $p$-value $(0.00)$ is less than the level of significance of (0.05); therefore we reject the null hypotheses and conclude that a positive and significant relationship exists between YouTube, sales growth, market share and profitability. This finding however supports the views of [30] who said that: "YouTube provides a forum for people to connect, inform, and inspire others across the globe and acts as a major distribution platform for original content creators and advertisers, large and small”. It is an impeccable means to test your ideas more cost-effectively than ever before, having the potential of being an integral part of any small business marketing [25] Some large companies are using YouTube to find video talent [18]. Million unique users visit YouTube each month, with billions videos viewed each day, with this type of engagement potential, leading brands are committing considerable resources to build and expand their profiles on the social media channel. YouTube created a "hyperactive" audience. "This audience is hyperactive because it has been moved beyond being active in creating meaning to also being active in the appropriation, creation, distribution, and consumption of content made possible through technological innovations like YouTube" [18].

Moderating role of power supply on the relationship between social media marketing and business success.

The partial correlation coefficient result shown in Table 4 indicated that power supply significantly moderate the relationship social media marketing and business success of automobile car dealers in Port Harcourt. The zero order correlation relationship social media marketing and business success shows the correlation coefficient where power supply is not moderating the variables; and this is fairly high at (0.881) and statistically significant $p$-value $(0.000)$. The partial correlation controlling for power supply however is a (0.440) and statistically significant $p$-value $(0.000<0.05)$. The observed positive "relationship" between social media marketing and business success is due to underlying relationships between each of those variables and power supply. However, from the aforesaid 
discussion, it is revealed that power supply significantly moderates the relationship between social media marketing and business success of automobile car dealers in Rivers State. This finding corroborates with that of [31] as quoted in [32] who considered steady power supply as one of the obstacles to the growth of online business transaction in Nigeria. An improved or steady power supply enhance the growth of online business, owing to the fact that with constant power supply, business owners can easily power their devices that will enable them to be connected online.

\section{Summary and Findings}

The data collected to carry out this research were analyzed and the results have been discussed.

1) There is a significant relationship between Facebook and sales growth, market share and profitability of automobile car dealers in Rivers State.

2) There is a significant relationship between Twitter and sales growth, market share and profitability of automobile car dealers in Rivers State.

3) There is a significant relationship between YouTube and sales growth, market share and profitability of automobile car dealers in Rivers State.

4) Power supply significantly moderates the relationship between social media marketing and business success of automobile car dealer in Rivers State.

However, from the above summary of findings, it is obvious that the ability of automobile car dealers to increase their level of business success are predicted on their ability to constantly improves on their usage of the social media platforms better than their competitors.

\section{Conclusion}

Based on the discussion of findings, empirical data analyses, and the review of empirical related literature thus far, we posit the following conclusions:

1) Facebook significantly influences sales growth of automobile car dealers in Rivers State.

2) Facebook significantly influences market share of automobile car dealers in Rivers State.

3) Facebook significantly influences profitability of automobile car dealers in Rivers State.

4) Twitter significantly influences sales growth of automobile car dealers in Rivers State.

5) Twitter significantly influences market share of automobile car dealers in Rivers State.

6) Twitter significantly influences profitability of automobile car dealers in Rivers State.

7) YouTube significantly influences sales growth of automobile car dealers in Rivers State.

8) YouTube significantly influences market share of automobile car dealers in Rivers State. 
9) YouTube significantly influences profitability of automobile car dealers in Rivers State.

10) Power supply significantly influences the relationship between social media marketing and business success of automobile car dealers in Rivers State.

\section{Theoretical Implications of the Study}

The use of social media marketing tools as a strategy to improve business success of automobile car dealers in Rivers State should be recognized by automobile dealers since both theoretical and empirical evidence has proven that the dimensions of social media marketing positively correlate with business success. Theoretically, automobile car dealers should recognize that the social media marketing platforms can help increase or reduce their level of business viability, customer attraction and sales volume. In the context of automobile car dealers in Rivers State, our study has these specific theoretical implications.

1) This study has brought to the fore the significance of social media marketing platforms and how its adoption can help automobile car dealers to enhance their level of business success.

2) This study revealed the Facebook, Twitter and YouTube dimensions of social media marketing variables that automobile car dealers can manipulate to increase their level of business success.

3) The aforementioned dimensions should be adopted as strategies, building blocks and guidance to automobile car dealers in Rivers State.

4) Power Supply moderated and had positive and strong significant relationships on social media marketing and business success.

From the findings and discussion, we developed a new social media marketing and business success model presented in Figure 2.

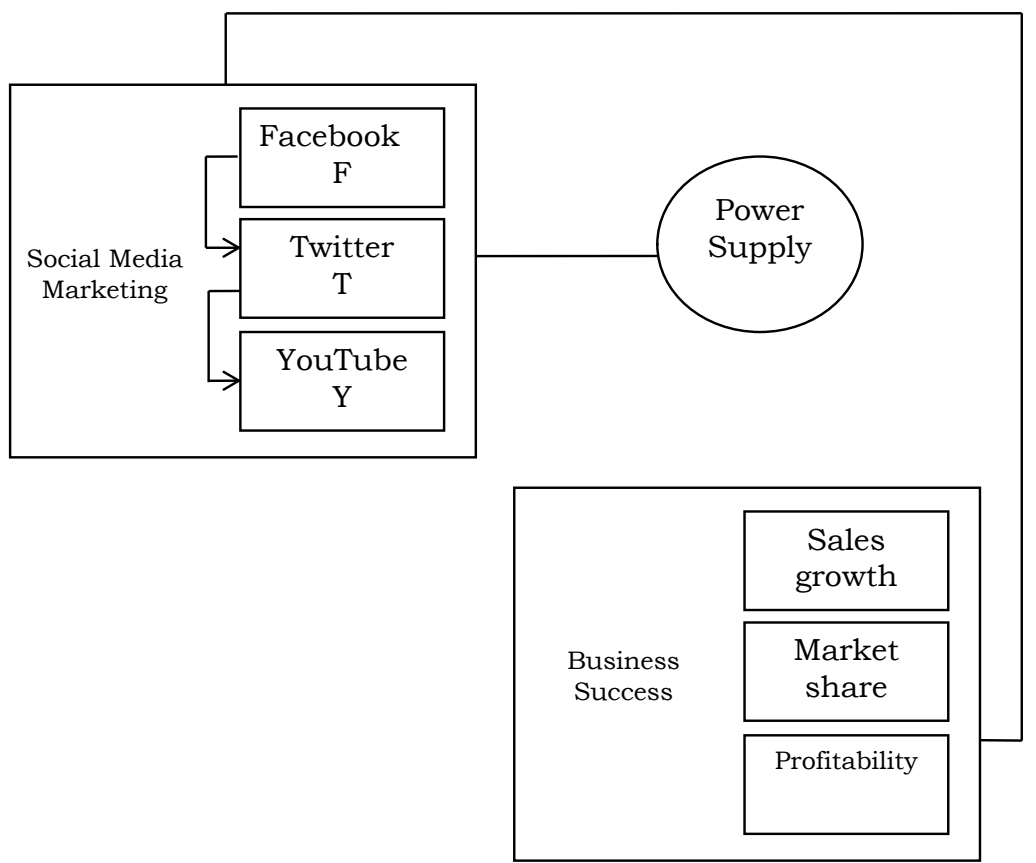

Figure 2. Social media marketing and business success model. 


\section{Practical Implications}

The practical implications drawn from our conclusion are:

Companies that effectively apply and exploit the dimensions of social media marketing such as Facebook, Twitter and YouTube as strategies will have significant increase in sales growth, market share and profitability.

\section{Recommendations}

The main objective of this study was to empirically establish the relationship between social media marketing and business success as well as to proffer useful recommendations for corporate performance through the adoption of efficient social media marketing platforms and strategies.

Based on the findings and conclusions drawn from the study, the researcher therefore recommends that:

1) Firms should make Facebook, Twitter and YouTube advertisements to be more appealing, trendy and catchy so that online users will patronize the product.

2) Advertisers should give all the details that are needed for easy patronage of the products.

3) Applications should be made accessible from the cell phones especially the advertisements. The advertising agencies should adopt Facebook, twitter and YouTube as a platform for advertising their clients' products as it has been proven from this study as being effective in selling the advertised products.

4) The automobile car dealers should also adopt this platform more for advertising their products and services.

5) It is imperative that automobile car dealers stake their claim now on basic social media platform, like Facebook, twitter and YouTube populate those sites with the types of information consumers are most likely to search for products and services, hours of operation, contact phone number, physical address, etc.

6) Social media can be effective, but in order to work its magic, automobile car dealers should choose the kinds of social sites they use wisely for their business.

\section{Contribution to Knowledge Suggestion for Further Studies}

This study has contributed immensely to knowledge by extensively considering a mediating factor (power supply) to examine its effect on the independent variable (social media marketing) and dependent variable (business success) which is not common with most empirical studies. Also, three variables of both independent and dependent variables were used as against one or two that could be used in other studies. This however, is a distinct layout on the study. This study has examined three dimensions of social media marketing. However there are other dimensions that are not examine in this study. More empirical research expected to further examine other social media platforms that can impact on business success of automobile products, such as Myspace, Linkedln, Friendster, Kyte and Instagram. Again, the researcher suggests that similar study should be carried 
out in other states of the country so that we can compare the outcome with that of this present study.

\section{References}

[1] Nick, S., Robert, W. and Catherine, Z. (2011) The Social Media Management Handbook: Everything You Need to Know to Get Social Media Working in Your Business. John Wiley \& Sons, Inc.

[2] Daniel, E. (2016) Provision of Electronic Banking in the UK and the Republic of Ireland. International Journal of Bank Marketing, 17, 72-82.

https://doi.org/10.1108/02652329910258934

[3] Nwokah, N.G. and Gladson-Nwokah, J. (2015) Impact of Social Network on Customer Acquisition in the Banking Industry in Nigeria. Information and Knowledge Management, 5, 150-163.

[4] Hofer-Shall, Z. (2010) The Forester Wave: Listening Platforms, Forrester Research. Information for Parents and Educators. https://www.facebook.com/help/parents

[5] Rui, H., Andrew, W. and Eizaeth, W. (2009) Follow the Tweets. Sloan Management review, 30, 29-34.

[6] Auffermann, K. (2010) Achieving Success with Social Media: Public Relations Tactics. International Journal of Bank Marketing, 16, 80-86.

http://www.prsa.org/Intelligence/Tactics/Articles/view/8702/1017/Achieving_succe ss_with_social_media

[7] Geier, T.J., Jeff, J.T., Lyons, M. and Markovitz, A. (2009) The 100 Greatest Movies, TV Shows, Albums, Books, Characters, Scene, Episodes, Songs, Dresses, Music Videos, and Trends That Entertained u over the 10 Years. Entertainment Weekly (New York (1079/1080), 74-64.

[8] Better, H. (2015) Business Success: The Doing Definition. https://www.linkedin.com/pulse/business-success-doing-definition-brett-hersh/

[9] Acar, A.S. and Polonsky, M. (2007) Online Social Networks and Insights into Marketing Communications. Journal of Internet Commerce, 6, 55-72. https://doi.org/10.1080/15332860802086227

[10] Bernhardt, J.M., Mays, D., Eroğlu, D. and Daniel, K.L. (2009) New Communication Channels: Changing the Nature of Customer Engagement. Social Marketing Quarterly, 15, 7-15. https://doi.org/10.1080/15245000902960924

[11] Charity, P. (2011) Social Media Marketing: Measuring Its Effectiveness and Identifying the Target Market. Journal of Undergraduate Research, 14, 20-30.

[12] Reino, S. and Hay, B. (2016) The Use of YouTube as a Tourism Marketing Tool. Tourism Travel and Research Association, 96, 1-2.

[13] Sana, R., Moez, L. and Esmail, S. (2011) Impact of Facebook Usage on Students Academic Achievement: Role of Self-Regulation and Trust. Electronic Journal of Research in Educational Psychology, 9, 961-994.

[14] McLuhan, M. (2011) Understanding Media Today. International Mcluhan Studies, 1, 137-146.

[15] Emerson, R.M. (1976) Social Exchange Theory. Annual Review of Sociology, 2, 335-362. https://doi.org/10.1146/annurev.so.02.080176.002003

[16] Homans, G.C. (1958) Social Behaviour as Exchange. American Journal of Sociology, 63, 597-606. https://doi.org/10.1086/222355 
[17] Manglod, W.G. and Foculds, D.J. (2009) Social Media: The New Hybrid Element of the Promotion Mix. Business Horizons, 52, 357-365. https://doi.org/10.1016/j.bushor.2009.03.002

[18] Sisira, N. (2011) Social Media and Its Role in Marketing. International Journal of Enterprise and Business Systems, 1, 2230-8849.

[19] Kaplan, A.M. and Michael, H. (2010) Users of the World Unite: The Challenges and Opportunities of Social Media. Business Horizon, 53, 59-68. https://doi.org/10.1016/j.bushor.2009.09.003

[20] Roberts, S., Felt, M. and Bly, R.W. (2001) Internet Direct Mail: The Complete Guide to Successful E-Mail Marketing Campaign. NTC Business Books, Chicago.

[21] Gan, C. and Clemes, M. (2006) A Logic Analysis of Electronic Banking in New Sea Land. International Journal of Banking Marketing, 24, 360-383. https://doi.org/10.1108/02652320610701717

[22] Ramsaran-Fowdar, R.R. and Fowdar, S. (2013) The Implications of Facebook Marketing for Organizations. Contemporary Management Research, 9, 73-84. http://www.cmr-journal.org/article/viewFile/9710/pdf_1

[23] Pikkarainan, T., Pikkarainen, K., Karjaluoto, H. and Pahnila, S. (2007) Consumer Acceptance of Online Banking: An Extension of the Technology Acceptance Model. Internet Research, 14, 168-180.

[24] Kevin, C., Kevin, O. and Sean, O. (2011) The Role of Twitter in the World of Business. International Journal of Business Data Communications and Networking, 7, 1-15. https://doi.org/10.4018/jbdcn.2011070101

[25] Brad, R. and Debra, S. (2009) How to Make Money with YouTube. McGraw Hill, New York.

[26] Muniz, A.M. and Thomas, C. (2001) Brand Community. Journal of Consumer Researcher, 27, 412-432. https://doi.org/10.1086/319618

[27] Ondrej, M. and Martins, M. (2014) Factors of Business Growth: A Decomposition of Sales Growth into Multiple Factors. WSEAS Transaction on Business and Economics, 11, 380-385.

[28] Casteleyn, J., Mottart, A. and Rutten, K. (2009) How to Use Facebook in Your Market Research. International Journal of Market Research, 51, 439-447. https://doi.org/10.2501/S1470785309200669

[29] Andrew, S. (2013) YouTube Marketing for Automotive Brands. http://www.thismoment.com/content-marketing-blog/?s=YouTube+Marketing+for + Automotive+Brands

[30] Roberts, K. (2010) Privacy and Perceptions: How Facebook Advertising Affects Its Users. Journal of Undergraduate Research in Communications, 1, 24-34.

[31] Raphael, T. (2013) Driving Growth in the Nigeria Economy with E-Commerce. This Day Live, Thursday 15, 2013.

[32] Michael, B. (2014) Four Ways You Can Use Social Media for Sales Growth. https://www.business2community.com/social-media/4-ways-can-use-social-media$\underline{\text { sales-growth-0957087 }}$ 